\title{
Bivalves and Gastropods of the Gulf of Tehuantepec, Mexico: A Checklist of Species with Notes on Their Habitat and Local Distribution
}

\author{
Eduardo Ríos-Jara, Ceciel-M. Navarro-Caravantes, Cristian-M. Galván-Villa, \\ and Ernesto Lopez-Uriarte
}

Laboratorio de Ecosistemas Marinos y Acuicultura, Departamento de Ecología, Centro Universitario de Ciencias Biológicas y Agropecuarias, Universidad de Guadalajara, Carretera a Nogales Km. 15.5, Las Agujas Nextipac, Zapopan, Jalisco 45110, Mexico

Correspondence should be addressed to Eduardo Ríos-Jara, edurios@cucba.udg.mx

Received 1 April 2009; Accepted 19 October 2009

Recommended by Ricardo Serrão Santos

The taxonomic composition of 160 species of bivalves and gastropods recorded in the Gulf of Tehuantepec is presented with information on their habitat and distribution along 10 different localities of the shoreline and 42 stations of the continental shelf. The species were on sandy and rocky beaches, coastal lagoons, estuaries, mangroves, rocky breakwaters of ports, and shallow subtidal areas (14-47 m depth). A total of 78 bivalve species and 82 gastropod species were recorded. Most of these were associated with sandy and rocky beaches and breakwaters of ports. The estuaries host 30 species and the coastal lagoons only two. In the shallow subtidal there were 18 gastropod species and 40 bivalve species representing $36.3 \%$ of all. This study adds 24 bivalve species and 29 gastropod species not recorded in previous studies for a total count of 213 species (102 bivalves and 111 gastropods) for Gulf of Tehuantepec.

Copyright ( $) 2009$ Eduardo Ríos-Jara et al. This is an open access article distributed under the Creative Commons Attribution License, which permits unrestricted use, distribution, and reproduction in any medium, provided the original work is properly cited.

\section{Introduction}

The tropical coastal environments are the most biologically diverse of all marine ecosystems but are being degraded worldwide by human activities potentially leading to numerous extinctions. Conservation efforts targeted toward them could help averting the loss of tropical biodiversity. However, the sustainable use of coastal living resources cannot be properly established without an adequate knowledge of the biodiversity. The molluscs are among the most diverse invertebrates in the coastal tropical environments and the vast majority are found intertidally, in estuaries and coastal lagoons, and in the shallow areas on the continental shelf $[1,2]$.

The first complete inventory of the subtropical and tropical malacological fauna of the western America is the huge monograph of Keen [3] which comprises approximately 3340 mollusc species, most of them bivalves and gastropods. Other catalogues also include the species of molluscs from the Mexican Pacific [4-6] and the revisions of the species from the Panamic Province made by Skoglund $[7,8]$ provide updated information including new species, redefinitions of taxonomic relationships, new records, and their geographic distributions. However, most of the literature on the molluscs from the Mexican Pacific refers to benthic communities of the Gulf of California [2, 9-16].

The molluscan fauna of the southernmost region of the Tropical Mexican Pacific has received little attention. The first inventories of molluscs from the Gulf of Tehuantepec were performed in the 1980s. Most of this research is included in not easily accessible technical reports and theses [17-19] or refers to specific localities and environments of the coast of Oaxaca $[20,21]$. More complete lists of species from this region are found in two different catalogues, one for the coast of Oaxaca, mainly from rocky and sandy beaches and from shallow subtidal areas as far as $39 \mathrm{~m}$ depth [22], and another one for the coast of Chiapas, collected in 10 different shoreline locations [23]. 


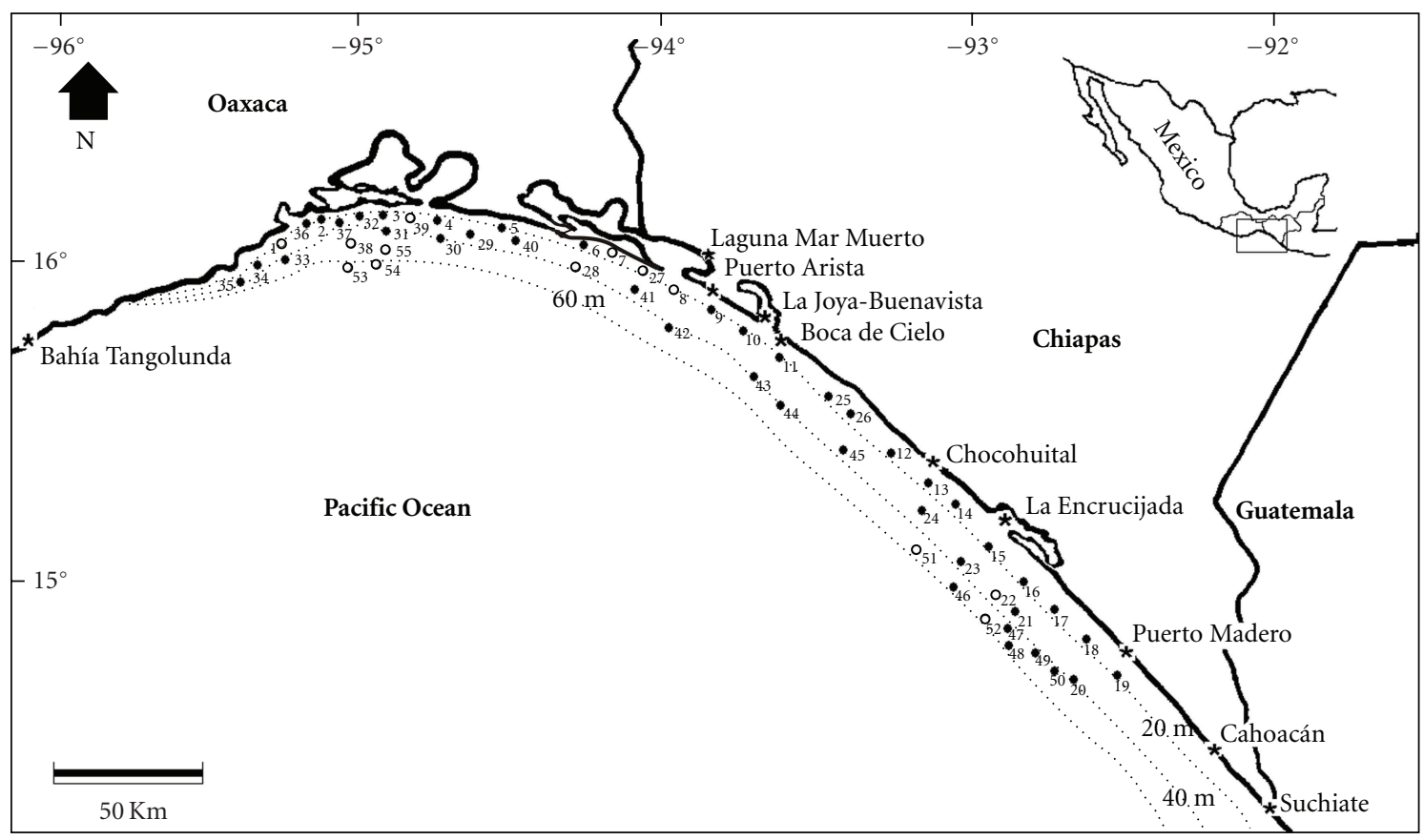

* Shoreline locations

- Stations on the continental shelf with registry of mollusks

○ Stations without registry of mollusks

Figure 1: The Gulf of Tehuantepec and sampling localities.

The present study deals with the species of bivalves and gastropods found in the most representative environments of the Gulf of Tehuantepec and includes a checklist of species with information on their habitat and distribution along 10 different localities of the shoreline and 42 stations of the shallow subtidal of the continental shelf. This list is an attempt to both provide a more complete inventory of the mollusc fauna of this region and update the taxonomic names including all synonymies and nomenclatural changes. In addition, the material collected was deposited in two replicate reference collections, one at the Universidad de Guadalajara in Jalisco and the other one at El Colegio de la Frontera Sur (ECOSUR) in Tapachula, Chiapas, Mexico.

\section{Methods}

The Gulf of Tehuantepec is located in the southeast part of the Mexican Pacific and extends from Puerto Angel, Oaxaca, to the Suchiate River in Chiapas, which is the limit between Mexico and Guatemala (Figure 1). This region has nearly $420 \mathrm{~km}$ of shoreline and covers an approximate area of $100000 \mathrm{~km}^{2}$ [24]. The region has a tropical warm subhumid climate with average annual temperature close to $26^{\circ} \mathrm{C}$ and numerous summer rains (annual rainfall $=2500$ $3000 \mathrm{~mm}$ ) making this region one of the wettest of Mexico [25]. Strong seasonal winds, the "Tehuantepec winds," and hurricanes cause high surf and waves during this period of the year [26]. Long sandy beaches extend to the edge of the continental shelf in a relatively homogeneous geological and geomorphological region with the sediments of the sand shores and the shelf mostly composed of medium sands, moderately well sorted presenting similar granulometry and mineralogical composition [27]. There is a complex hydrological system along the coastal plains with permanent rivers and temporal streams that form extensive coastal lagoons and estuaries with well-developed mangrove forest communities.

To perform the inventory of the gastropod and bivalve molluscs of the region, samplings and collections were performed from April to December of 2004 in two different types of locations: (a) 10 localities on the shoreline of the Gulf and (b) 55 stations on the continental shelf (Figure 1). In the localities of the shoreline, the field work was performed through direct search during excursions along the different environments and types of habitats of each locality. In the sandy beaches, the shells were collected along the shoreline from the intertidal and the supralittoral areas up to the beach berm and sand dunes where the molluscs frequently concentrate in shell deposits. Similarly, collection of shells was also performed from the sand barriers of the estuaries usually oriented shore-parallel and connected to the ocean by one or more restricted inlets.

In the subtidal area of the continental shelf, the molluscs were obtained on board of the shrimp vessel FIPESCO63 of the Instituto Nacional de la Pesca of the Mexican Government with a "semi-Portuguese" shrimp trawl net (length $=24.4 \mathrm{~m}$, mesh size $=50.8 \mathrm{~mm}$ ). Trawls were performed over 55 sampling stations at depths between 14 
and $65 \mathrm{~m}$. The average trawling time was of $61.56 \mathrm{~min}$ with an average speed of the vessel of $60.80 \mathrm{~m} / \mathrm{min}$ and an average distance covered during each trawl of $3735.5 \mathrm{~m}$. The total sampled area covered by the vessel was $330 \mathrm{~km}^{2}$, from station 19 located in the southeast end to station 35 in the northeast end.

All shells were washed with tap water, labeled, and stored in plastic bags in the laboratory (Laboratorio de Ecología de Manglares of the El Colegio de la Frontera Sur (ECOSUR) in the city of Tapachula, Chiapas). The living molluscs were also washed and the soft parts of the organisms were extracted, leaving only the shells for taxonomic identification; in some cases, the remnants of the adhered epibiota were removed.

The taxonomic identification of the species was performed using specialized bibliography $[3-6,30-33]$ and some mollusc catalogues of the region $[22,23,34]$. The taxonomic position of the species was updated according to the revisions of Skoglund $[7,8]$. The orders and families of gastropods were arranged according to Bouchet and Rocroi [28]; the orders are equivalent to the higher categories of the clades used by these authors.

\section{Results}

The bivalves and gastropods were registered in all shoreline localities and in 42 of the 55 subtidal stations of the continental shelf at depths between 14 and $47 \mathrm{~m}$. The bivalves belong to 7 orders, 23 families, and 78 species, and the gastropods belong to 5 orders, 33 families, and 82 species (Table 1). Most of the species (120) were collected in the shoreline localities ( 68 bivalves and 52 gastropods), and only 58 species (18 bivalves and 40 gastropods) were collected from the continental shelf. The number of species per family varies considerably ( 1 to 18 species). Seven families of bivalves (30.4\%) and 15 families of gastropods (45.5\%) are represented by one single species; the most diverse families of bivalves are Veneridae (18 species), Arcidae (8), and Tellinidae (7) and the most diverse families of gastropods are Calyptraeidae (12), Muricidae (9), and Fissurellidae (6).

A large majority of species of the bivalves and gastropods collected from the shoreline locations of the Gulf are associated with sandy (71) and rocky (55) substrata of beaches and breakwaters of ports (Table 2). The estuaries host 30 species and only two are exclusive of the coastal lagoons. Many species of bivalves (18) and gastropods (40) are associated with the sea bottom of the continental shelf, representing the $36.3 \%$ of all the species found.

In general, the localities with more than one type of habitat have a larger number of species. More species of bivalves and gastropods were recorded in the estuaries of Suchiate, Cahoacán, and Boca de Cielo (sandy beach and mangrove) than in La Encrucijada, La Joya Buenavista, and Chocohuital (mangrove). These shallow water bodies contain a distinctive group of species, some living on the roots of the red mangrove Rizophora mangle but most of them associated to the sandy and muddy substrata, sometimes forming aggregations of individuals as in the case of the so-called "pata de mula" clams (Anadara spp).
The bivalves found in the Gulf of Tehuantepec are typically associated to soft substrata. In particular the semiinfaunal and infaunal forms were mostly found in the sandy beaches or in the muddy or sandy areas of the mangrove estuaries and lagoons but many of these species were also recorded in the shallow subtidal stations on the continental shelf. Since the shells of most bivalves which live in the shallow subtidal areas are washed onto the shore and become incorporated into sand beach as shell deposits, many species reported here separately in the sandy beaches and in the shallow subtidal coincide in both habitats. These bivalves comprise a prolific assemblage of species living in the tidal and subtidal parts of the sandy shores.

Although the adding of shells washed up on a sandy beach into a sandy beach assemblage not accurately represents the living fauna in the sandy beach habitat, there is a characteristic assemblage that certainly includes many species that extend their distribution through the intertidal zone and may be considered inhabitants of the sandy beaches. In this group the chiones and tivelas, and the species of Cardites, Divalinga, Pitar, Chione, Mulinia, Donax, and Sanguinolaria frequently are found in the sandy beaches of the Gulf of Tehuantepec. Among the gastropods, the Naticidae and Nassariidae include species living in the tidal areas of sand beaches and bars; also the olives are common on intertidal or shallow subtidal sandy substratum.

A few epifaunal bivalves live adhered to the mangrove roots of estuaries and coastal lagoons or to the rocky beaches or breakwaters of ports. This group includes the mussels Choromytilus palliopunctatus, Mytella guyanensis, $M$. speciosa, and M. strigata, the oysters Saccostrea palmula, Striostrea prismatica, Isognomon janus, and I. recognitus, and the thorny chama Chama echinata. Other epifaunal bivalves recorded in the continental shelf are the pearl oyster Pinctada mazatlanica, the scallops Argopecten ventricosus, and Leptopecten tumbezensis and the lime oyster Spondylus limbatus. Odd valves, more frequently the unattached valve of mussels, oysters, and scallops, were also found in the sandy beaches.

Gastropods found in the Gulf are mostly associated to the marine environment. Forty species were collected during the shrimp trawls on the continental shelf at depths between 14 and $47 \mathrm{~m}$, or in rocky (33 spp.) and sandy beaches (16 spp.) of the shoreline localities. Only 19 species of gastropods are associated to estuarine habitats, and particularly to the mangrove forest of the estuaries.

Considerable changes in species composition of bivalves and gastropods occur between localities and habitats with many species being exclusive of one type of habitat. Uncommon species (frequency of occurrence less than $25 \%$ in the localities with the same type of habitat) comprised $71.16 \%$ of all the species found in the Gulf. Approximately $64 \%$ occurred in only one type of habitat and were considered habitat-exclusive (Table 3 ). In the estuaries and coastal lagoons, the habitat-exclusive species formed only $5 \%$, including those associated to mangroves.

The nine species that are exclusive to the mangrove habitat were recorded alive; among these, the painted nerite Theodoxus luteofasciatus, the banded periwinkle Littorina 
TABle 1: Bivalves and gastropods of the Gulf of Tehuantepec, Mexico. Systematic classification according to Keen [3], modified by Skoglund $[7,8]$. The orders (= clades) and families of gastropods according to Bouchet and Rocroi [28]. ${ }^{*}$ : species not recorded in previous studies of the Gulf of Tehuantepec. Numbers between parentheses ( ) indicate the localities where the species were recorded according to the list of Table 2 . The depth range in meters is indicated between squared brackets [ ] for those species collected in the continental shelf. SB: sandy beach; M: mangrove; CL: coastal lagoon; RB: rocky beach, CS: continental shelf.

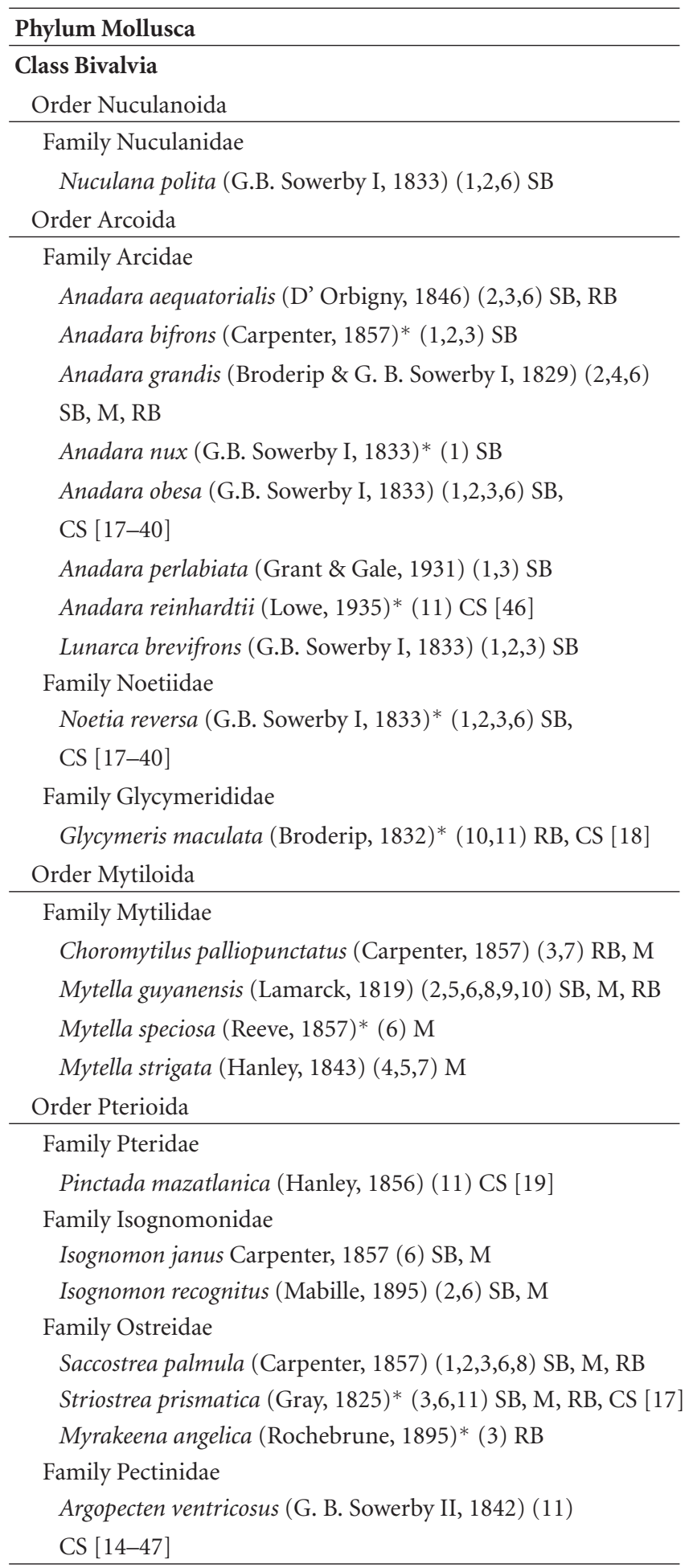

TABle 1: Continued.

Phylum Mollusca

Leptopecten tumbezensis (D’ Orbigny, 1846)* (3) SB

Family Spondylidae

Spondylus limbatus G.B. Sowerby II, 1847 (11) CS [28]

Order Veneroida

Family Carditidae

Cardites laticostata (G.B. Sowerby I, 1833) $(1,2,3)$ SB

Family Corbiculidae

Polymesoda inflata (Philippi, 1851) $(1,4,6)$ SB, M

Polymesoda meridionalis (Prime, 1869) (1) SB

Family Lucinidae

Ctena mexicana (Dall, 1901)* (10) RB

Divalinga eburnea (Reeve, 1850) (2) SB

Lucinisca fenestrata (Hinds, 1845) (1) SB

Parvilucina approximata (Dall, 1901)* $(2,6) \mathrm{SB}$

Pegophysema edentuloides (Verrill, 1870) (11) CS [17]

Family Ungulinidae

Diplodonta sericata (Reeve, 1850$)^{*}(1,2,6,8,9) \mathrm{SB}, \mathrm{RB}$

Family Chamidae

Chama echinata Broderip, 1835 (10) RB

Family Cardiidae

Americardia biangulata (Broderip \& G.B. Sowerby I, 1829)*

(10) RB

Laevicardium clarionense (Hertlein \& Strong, 1947)* (10) RB

Trachycardium consors (G.B. Sowerby I, 1833)* (10) RB

Trachycardium panamense (G.B. Sowerby I, 1833) $(1,2,11)$

SB, CS [28]

Trachycardium procerum (G.B. Sowerby I, 1833)* (11) CS [20] Trachycardium senticosum (G.B. Sowerby I, 1833) $(1,2,3,6)$ SB

Trigoniocardia obovalis (G.B. Sowerby I, 1833) $(1,2,10)$ SB, RB

Family Veneridae

Chione amathusia (Philippi, 1844) $(1,2,10)$ SB, RB, CS [17]

Chione pulicaria (Broderip, 1835)* (11) CS [17-43]

Chione subimbricata (G.B. Sowerby I, 1835)* (10) RB

Chione subrugosa (Wood, 1828) $(6,9,10) \mathrm{SB}, \mathrm{RB}$

Chione undatella (G.B. Sowerby I, 1835) (2) SB

Cyclinella saccata (Gould, 1851)* (11) CS [17]

Dosinia dunkeri (Philippi, 1844) $(6,9)$ SB, RB

Dosinia ponderosa (Schumacher, 1817) (11) CS [17-46]

Periglypta multicostata (G.B. Sowerby I, 1835)* (11) CS [17]

Pitar concinnus (G.B. Sowerby I, 1835) (1) SB

Pitar lupanaria (Lesson, 1830) $(1,2,6) \mathrm{SB}$

Pitar roseus (Broderip \& G.B. Sowerby I, 1829) $(1,2,3)$ SB

Pitar tortuosus (Broderip, 1835)* (2) SB

Protothaca asperrima (G.B. Sowerby I, 1835) $(2,9)$ SB, CL

Protothaca macgintyi (Olsson, 1961)* $(1,2,3) \mathrm{SB}$

Protothaca metodon (Pilsbry \& Lowe, 1932) (1) SB

Tivela byronensis (Gray, 1838) (2,3,6,10) SB, RB

Tivela delessertii (Sowerby, 1854) (10) RB 
Table 1: Continued.

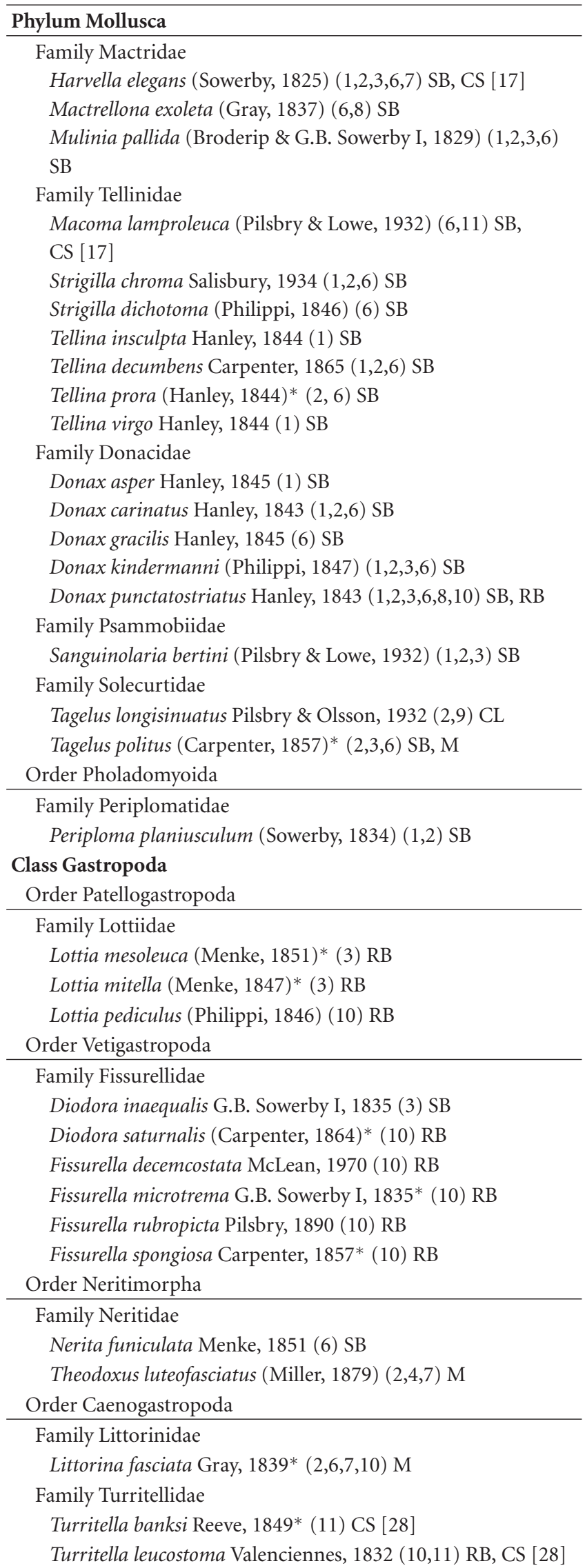

Table 1: Continued.

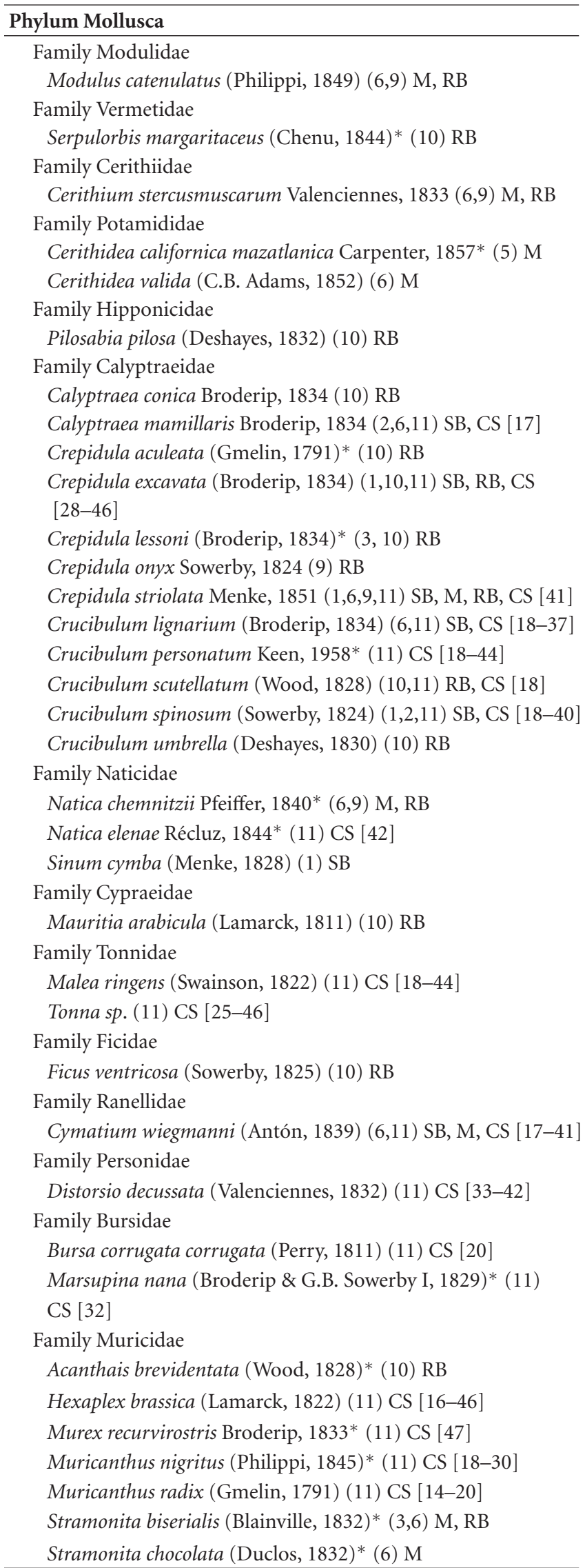


TABle 1: Continued.

\begin{tabular}{|c|}
\hline Phylum Mollusca \\
\hline Thais kiosquiformis (Duclos, 1832) $(1,6,11) \mathrm{SB}, \mathrm{M}$, CS [17] \\
\hline Thais triangularis (Blainville, 1832) (10) RB \\
\hline Family Buccinidae \\
\hline Cantharus ringens (Reeve, 1846)* (10) RB \\
\hline Cantharus sanguinolentus (Duclos, 1833)* (10) RB \\
\hline Engina jugosa (C.B. Adams, 1852)* (10) RB \\
\hline Northia northiae (Griffith \& Pidgeon, 1834) (11) CS [17-26] \\
\hline Phos crassus Hinds, 1843 (11) CS [20] \\
\hline Family Columbellidae \\
\hline Costoanachis nigricans (Sowerby, 1844)* (6) M \\
\hline Family Melongenidae \\
\hline Melongena patula (Broderip \& G.B. Sowerby I, 1829) (11) \\
\hline CS $[16-41]$ \\
\hline Family Nassariidae \\
\hline Nassarius bailyi (Pilsbry \& Lowe, 1932) (6) SB \\
\hline Nassarius luteostoma (Broderip \& G.B. Sowerby I, 1829)* \\
\hline$(6,9) \mathrm{SB}, \mathrm{M}, \mathrm{RB}$ \\
\hline Nassarius wilsoni (C.B. Adams, 1852)* (9) RB \\
\hline Family Fasciolaridae \\
\hline Fusinus dupetitthouarsi (Kiener, 1840) (11) CS [14-47] \\
\hline Pleuroploca granosa (Sowerby, 1825)* (11) CS [16-46] \\
\hline Family Harpidae \\
\hline Harpa crenata Swainson, 1822 (11) CS [26-46] \\
\hline Family Olividae \\
\hline Agaronia propatula (Conrad, 1849) (6) SB, M \\
\hline Oliva incrassata Lightfoot, $1786(5,11) \mathrm{M}, \mathrm{CS}$ [18-29] \\
\hline Oliva polpasta Duclos, $1833(5,11) \mathrm{M}, \mathrm{CS}[28-42]$ \\
\hline Oliva splendidula Sowerby, 1825* (11) CS [19-42] \\
\hline Family Olivellidae \\
\hline Olivella volutella (Lamarck, 1811) (308) SB, M, RB \\
\hline Olivella zanoeta (Duclos, 1835) (50) SB, M \\
\hline Family Vasidae \\
\hline Vasum caestus (Broderip, 1833)* (11) CS [18] \\
\hline Family Mitridae \\
\hline Mitra swainsonni Broderip, 1836* (11) CS [46] \\
\hline Family Cancellaridae \\
\hline Cancellaria obesa (Sowerby, 1832)* (11) CS [26] \\
\hline Cancellaria solida Sowerby, 1832* (11) CS [18] \\
\hline Family Conidae \\
\hline Conus archon Broderip, 1833* (11) CS [46] \\
\hline Conus patricius Hinds, 1843 (11) CS [14-30] \\
\hline Conus poormani Berry, 1968* (11) CS [47] \\
\hline Conus recurvus Broderip, 1833* (11) CS [32] \\
\hline Conus tornatus G.B. Sowerby I, 1833* (11) CS [32] \\
\hline Family Turridae \\
\hline Polystira picta (Reeve, 1843)* (11) CS [41] \\
\hline Order Heterobranchia \\
\hline Family Ellobiidae \\
\hline Melampus carolianus (Lesson, 1842) (6) SB \\
\hline
\end{tabular}

fasciata, and the mussels Mytella speciosa and M. strigata were relatively abundant and frequent in the roots of the red mangrove Rizophora mangle. The razor shell Tagelus longisinuatus was found in the muddy bottoms of the coastal lagoons. In the hard substratum of the rocky beaches and the rocky breakwaters of ports, there were 33 exclusive species (20.6\%). The bivalves Americardia biangulata and Choromytilus palliopunctatus and the gastropods Crepidula lessoni, Calyptraea conica, and Crucibulum umbrella were the most abundant species in this habitat.

The largest number (40 spp.) of exclusive species was recorded in the shallow areas of the continental shelf while the sandy beaches included 38 exclusive species ( 5 bivalves and 33 gastropods) which represent $23.8 \%$ of all species. However, since most of the species recorded in the sandy beaches were collected as shells of dead molluscs that once lived in the adjacent shallow subtidal areas of the shores, only the species collected alive in the intertidal zone may be considered as truly exclusive inhabitants of the sandy beaches.

Notably, when both habitats are considered as one continuous environment (e.g., the intertidal and subtidal parts of the sandy shores), the number of species increases to 115 (48.8\% are exclusive of this environment). The few species collected alive in the intertidal of the sandy shores were burrowed to avoid being washed away by waves and currents as in the case of the gastropods Agaronia propatula, Olivella volutella, and O. zanoeta and the bivalve Donax carinatus.

\section{Discussion}

Marine molluscs are among the most diverse group of shelf macrobenthos [35]. Recent studies on the diversity gradients of the molluscan fauna of the Northern Hemisphere, both in the Western and Eastern Pacific, indicate that species richness increases toward the tropics $[35,36]$. This increase has a stepwise form, with the steps corresponding to provincial boundaries that form at the boundaries between major water masses or water types [37, 38]; this diversity gradient has been documented for many marine taxonomic groups [39].

In the Northeastern Pacific, the number of species of bivalves increases notably between latitudes $5^{\circ} \mathrm{N}$ (Peru) and $23^{\circ} \mathrm{N}$ (Sinaloa, Mexico) but reaches maximal values between 9 and $14^{\circ} \mathrm{N}$ (Panama-Chiapas) [35]. This diversity gradient is very similar for gastropods of the same region $[35,36]$. Results of the present study coincide with this general pattern, with the Gulf of Tehuantepec $\left(14-16^{\circ} \mathrm{N}\right)$ being within a region of high richness of molluscs.

This high diversity is well documented in the monograph of Keen [3] which is the most complete compendium of molluscs from the Mexican Pacific. This publication records approximately 800 species of bivalves and 2440 species of gastropods with almost $50 \%$ found in Mexican waters. The more recent reviews of Skoglund $[7,8]$ revealed an additional 478 species of bivalves and gastropods. However, although Keen's monograph includes the geographical distribution of the species, in most cases it does not give details of the 
TABLE 2: Distribution of the species of bivalves and gastropods in the localities and habitats of the Gulf of Tehuantepec.

\begin{tabular}{lccc}
\hline Locality & Givalves & Gastropods & Total \\
\hline (1) Estero Suchiate (sandy beach, estuary + mangrove) & 37 & 5 & 42 \\
(2) Estero Cahoacán (sandy beach, estuary + mangrove) & 39 & 5 & 44 \\
(3) Puerto Chiapas (sandy beach, rocky breakwater) & 22 & 8 & 30 \\
(4) La Encrucijada (estuary + mangrove) & 3 & 1 & 4 \\
(5) La Joya Buenavista (estuary + mangrove) & 2 & 4 & 6 \\
(6) Estero Boca de Cielo (sandy beach, estuary + mangrove) & 32 & 20 & 52 \\
(7) Estero Chocohuital (estuary + mangrove) & 4 & 2 & 6 \\
(8) Puerto Arista (sandy beach) & 4 & 1 & 5 \\
(9) Laguna Mar Muerto (coastal lagoon + mangrove) & 7 & 8 & 15 \\
(10) Bahía Tangolunda (sandy and rocky beach) & 14 & 21 & 35 \\
(11) Continental shelf (sandy bottom) & 18 & 40 & 58 \\
\hline Habitat & & 19 & 30 \\
\hline Estuary + mangrove & 11 & 0 & 2 \\
Coastal lagoon + mangrove & 2 & 33 & 55 \\
Rocky beach and rocky breakwater & 22 & 16 & 58 \\
Sandy beach & 55 & 40 & \\
Sandy bottom of the continental shelf & 18 & & \\
\hline
\end{tabular}

localities and it cannot be used to know the specific richness of a particular region. Other catalogues of molluscs from the Mexican Pacific also lack this information [4-6, 30].

With a total of 160 species, 56 families, and 10 orders of bivalves and gastropods, the present study compiles the largest biodiversity of molluscs recorded for the Gulf of Tehuantepec. Previous studies report different species composition compared to the present study (Table 4): GonzálezBulnes [17] with only 8 species in common (3.0\%); GómezFarías [18] with 12 species (5.0\%); Holguin Quiñones and González-Pedraza [22] with 54 species (33.12\%); SevillaHernández [23] with 74 species (30.7\%); De León-Herrera [20] with 5 species (2.6\%); and Ramírez-González and Barrientos-Luján [29] with 18 species (7.7\%). Differences in species composition are mostly related to the sampling effort and the method used to collect the molluscs. For example, González-Bulnes [17] and Gómez-Farías [18] report very different species mostly because they used a geological grab to collect the organisms. The geological grabs are very efficient in collecting the infaunal forms from the soft sediments in subtidal areas, including the smaller shells and the juveniles; these forms comprise most of the species of bivalves and many small gastropods not collected with trawling nets. Therefore, different sampling methods performed in the different localities and habitats complement each other to have a better compilation of the diversity of molluscs from the Gulf.

The present study adds 24 species of bivalves and 29 species of gastropods not reported in previous studies-but certainly included in Keen's [3] monography and in other catalogues for this region-for a total count of 213 species (102 bivalves and 111 gastropods) recorded in the Gulf of Tehuantepec. These figures, however, still underestimate the diversity of molluscs of this region due to lack of sampling, especially in the shallower and deeper zones of the shelf. Below $50 \mathrm{~m}$ depth the appropriate equipment and expertise is particularly required; also the areas less than $10 \mathrm{~m}$ depth along the open shoreline regions are difficult to access because of the surf and strong currents except for some locations where sampling may be performed during SCUBA diving. There is certainly a different group of species living in the deeper parts of the shelf but their composition in the Gulf of Tehuantepec is still not well documented. Indeed, studies on the bathymetric distribution of molluscs in other regions of the Mexican Pacific have shown that the highest diversity is found in the coastal fringe ( $<20 \mathrm{~m}$ depth) and the number of species remains relatively high across the shelf as far as the $100 \mathrm{~m}$ depth (e.g., $[2,9,15,40,41])$.

Recently, because of the ongoing mass extinction of species due to human activities, the question of how many species occur in certain areas or habitats has grown more important [42]. Most of these species are being lost in the tropics [43]. Therefore, it is important to have a reasonable estimate of how many species are present in a particular environment in order to have a base against which to measure the losses.

The Gulf of Tehuantepec has been identified by the CONABIO (Comisión Nacional para el Conocimiento y Uso de la Biodiversidad) as a region of high priority for the conservation of biodiversity [44]. However, there are no complete inventories for most of the marine animal groups. The region holds some of the tallest mangroves in Mexico, with trees reaching heights of $25 \mathrm{~m} \mathrm{[45],} \mathrm{in}$ an almost continuous hydrological system with swamps, estuaries, lagoons, and mangrove forests running northwest to southwest along the coastal plain of the Gulf. These environments serve as a nursery to fish and invertebrates, and provide refuge for many endangered animals [46]. 


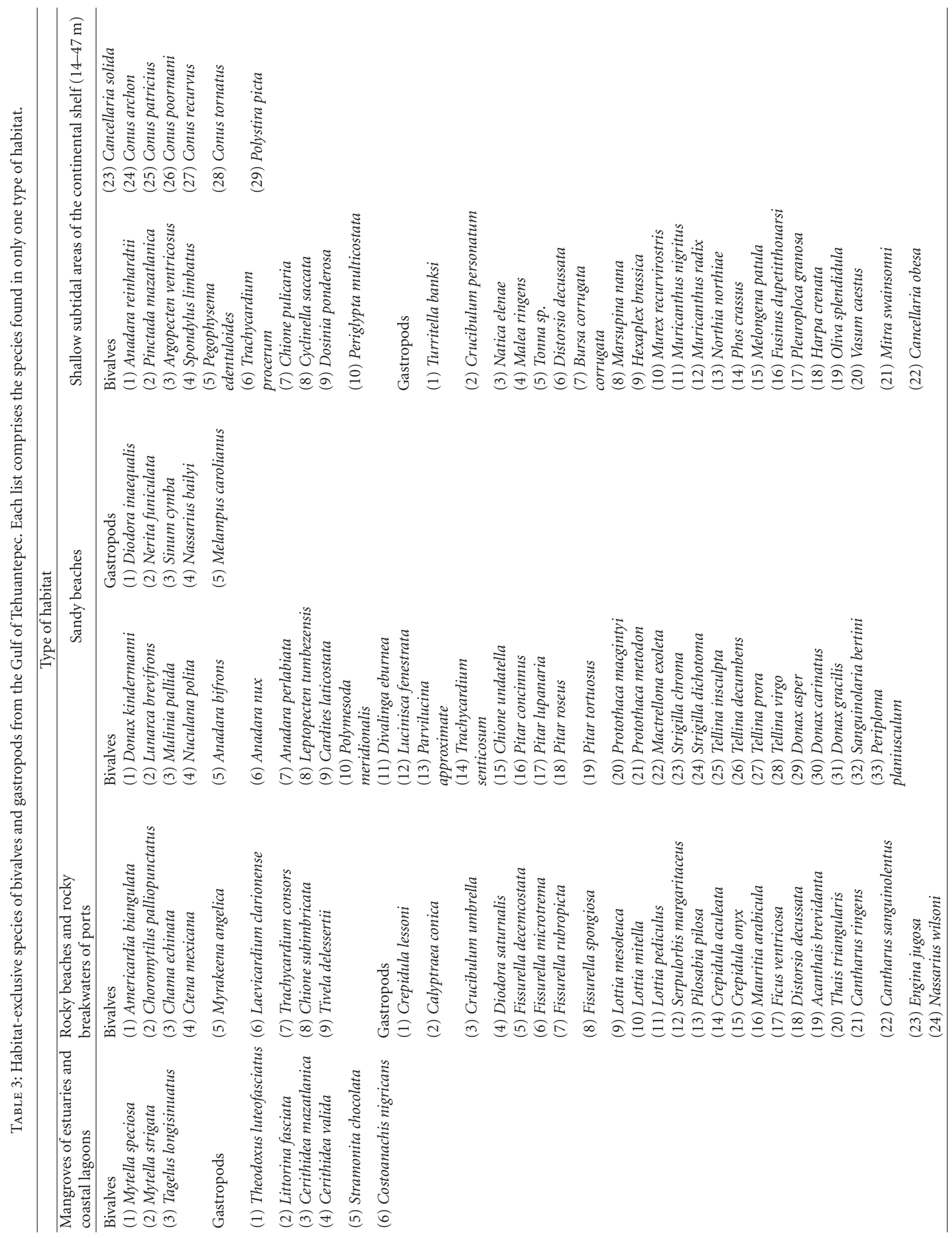


TABLE 4: Studies on the molluscan fauna from the Gulf of Tehuantepec. The habitats and the sampling method of each study are detailed for comparisons. The shared species are those reported in other studies and in the present checklist.

\begin{tabular}{|c|c|c|c|c|}
\hline Locality & Habitat (sampling method) & Total species & Shared species & Reference \\
\hline \multirow[t]{2}{*}{ Gulf of Tehuantepec } & $\begin{array}{l}\text { continental shelf } \\
\text { (geological grab) }\end{array}$ & 39 bivalves & 5 & González-Bulnes [17] \\
\hline & & 68 gastropods & 3 & \\
\hline \multirow[t]{2}{*}{ Salina Cruz, Oax. } & $\begin{array}{l}\text { continental shelf } \\
\text { (geological grab) }\end{array}$ & 42 bivalves & 9 & Gómez-Farías [18] \\
\hline & & 46 gastropods & 3 & \\
\hline \multirow[t]{2}{*}{ Coast of Oaxaca } & $\begin{array}{l}\text { rocky and sandy beach, } \\
\text { continental shelf (direct } \\
\text { search) }\end{array}$ & 55 bivalves & 25 & $\begin{array}{l}\text { Holguín-Quiñones \& } \\
\text { González-Pedraza } \\
{[22]}\end{array}$ \\
\hline & & 98 gastropods & 29 & \\
\hline \multirow[t]{2}{*}{ Coast of Chiapas } & $\begin{array}{l}\text { estuary, coastal lagoon, } \\
\text { rocky and sandy beach } \\
\text { (direct search) }\end{array}$ & 78 bivalves & 42 & $\begin{array}{l}\text { Sevilla-Hernández } \\
\text { [23] }\end{array}$ \\
\hline & & 73 gastropods & 32 & \\
\hline \multirow[t]{2}{*}{$\begin{array}{l}\text { Central coast of } \\
\text { Oaxaca }\end{array}$} & rocky beach (direct search) & 5 bivalves & 1 & $\begin{array}{l}\text { De León-Herrera, } \\
{[20]}\end{array}$ \\
\hline & & 26 gastropods & 4 & \\
\hline \multirow[t]{2}{*}{$\begin{array}{l}\text { Bahías de Calacuta } \\
\text { (Huatulco), Oax. }\end{array}$} & $\begin{array}{l}\text { rocky and sandy beach } \\
\text { (direct search) }\end{array}$ & 30 bivalves & 7 & $\begin{array}{l}\text { Ramírez-González \& } \\
\text { Barrientos-Luján [29] }\end{array}$ \\
\hline & & 59 gastropods & 11 & \\
\hline \multirow[t]{2}{*}{ Gulf of Tehuantepec } & $\begin{array}{l}\text { estuary, coastal lagoon, } \\
\text { rocky and sandy shores, } \\
\text { continental shelf (direct } \\
\text { search, trawling net) }\end{array}$ & 78 bivalves & 54 & Present study \\
\hline & & 82 gastropods & 53 & \\
\hline \multirow{3}{*}{\multicolumn{2}{|c|}{ Total species registered in the Gulf of Tehuantepec }} & Bivalvia & 102 & \\
\hline & & Gastropoda & 111 & \\
\hline & & Total & 213 & \\
\hline
\end{tabular}

A good example of fieldwork conducted specifically to document molluscan richness for all size classes in a complex tropical coastal environment is the study by Bouchet et al. [47]. This massive collecting effort involving 400 day-persons at 42 discrete stations on a $295 \mathrm{~km}^{2}$ site on the west coast of New Caledonia, south-west Pacific, revealed 2738 species of marine molluscs. This is several times the number of species recorded from any area of comparable extension anywhere in the world. Schlacher et al. [48] suggest that three main factors had, separately or together, contributed to the underestimation of actual richness in many studies on tropical marine molluscs: (1) inadequate or insufficient coverage of spatial heterogeneity over the area of study (a high number of species may be found at only one station), (2) inadequate sampling of the very specialized species (those living in a very specific habitat), and (3) overemphasis on macromolluscs. On a total of 42 stations sampled in the continental shelf of the Gulf of Tehuantepec, $58.6 \%$ of the species were collected at single stations and $72.4 \%$ at three or less stations with a total of 1-8 individuals. A similarly high incidence of "ecological endemism" was found by Schlacher et al. [48] in the lagoon of Great Astrolabe Reef (Fiji) and Bouchet et al. [47] at the New Caledonia site. That their studies and the present study reach similar results despite very different sampling approaches and habitats (Schlacher et al. [48] sampled the soft bottom macrofauna of a lagoon, and Bouchet et al. [47] the molluscs from a coral reef) confirms the classical statement that many rare species are important in determining the structure of a marine benthic community and these rare species increase the richness component of the biological diversity. In addition, a large number of species of gastropods and bivalves are micromolluscs (Bouchet et al. [47] found that $33.5 \%$ of the species have an adult size smaller than $4.1 \mathrm{~mm}$ including at least five of the eight most speciose families and many species in the remaining three families) which require particular collecting/sorting attention and specific taxonomic expertise. This is why much of the literature focuses on macromolluscs (seashells) and tends to ignore or grossly underestimate the smaller species. Indeed, faunal surveys and inventories have a tendency to focus on the large species of "seashells" and neglect the smaller species. However, as Bouchet et al. [47] point out, the emphasis on macromolluscs is a perfectly valid approach when limited collecting and sorting resources are available in the field. 
In the present study, species represented only by empty shells are included because it is highly likely that they are part of the ecosystem at the spatial scale of the study site. Although some shells may be transported for several kilometers, they still will be found within the extensive area of this study. Those species represented only by empty shells may not have been collected alive for a number of possible reasons: they live in a habitat that is difficult to sample (e.g., narrow fissures or cavities in rocks, deep burrowing bivalves), they have a very specialized habitat (e.g., eulimids associated with echinoderms), they are exceedingly rare; they live at a season different from the study period, or several of these factors operate together. Also, some organisms have very seasonal or sporadic occurrences and no survey, whatever its intensity, can approach a complete coverage of such species if restricted to a single period of the year. The seasonality of molluscs is well documented in temperate waters, and there is also evidence that the occurrence of many tropical species is locally unpredictable [49-51].

Recent work has suggested that molluscan death assemblages in marine intertidal habitats are sufficiently representative of regional biodiversity to be used in rapid, comparative biodiversity assessments. The evaluation of beach-washed death assemblages [52-54] suggested that aggregations of dead shells may be useful indicators of biodiversity over regional scales. Most of these studies have found that death assemblages strongly represent the species richness of living fauna with from $60 \%-100 \%$ of species found alive also occurring as dead shells [55, 56]; poor live-dead agreement is restricted to shelves that are both narrow and anthropogenically eutrophied [57]. In general, a very strong agreement has been documented between the live community and death-assemblage estimates of species composition, richness, and abundance in benthic mollusc communities [56, 58-62]. Several findings have emerged from this work, including the recognition that out-of-habitat shell transportation affects relatively few individuals $[54,56$, 59]. These studies suggest that death-assemblage data can be used as an accurate proxy for species rank abundance in the live molluscan community.

The coastal ecosystems of the Gulf of Tehuantepec have great economic value. The main economic activity is the agriculture in the coastal plains but the artisan fishery and some tourism are also important. Dumping of organic and inorganic waste threatens the survival of many species. Development both residential and commercial is threatening these ecosystems due to the human population growth as well as tourism, which could displace mangrove communities. Economic and social problems have forced rural human communities to overexploit animal species through over hunting and fishing for the wildlife trade including several marine species, mammals, and reptiles such as turtles and iguanas. As a result, these species have acquired endangered status.

Immediate management and planning of conservation strategies are required for nearly the entire region. Agricultural expansion, shrimp farming, logging, and road construction activities continue to threaten the diversity of this region [46].
We did not recorded endemic species for this region; however, there are species that merit special attention, such as the pearl oyster Pteria sterna, which is mentioned in the NOM-059-ECOL-2001 (a Mexican standard for the wild terrestrial and aquatic flora and fauna species in danger of extinction, threatened, rare, and the subject ones to special protection).

Although many species are of commercial interest, there is no formal fishery or aquaculture of molluscs in the Gulf of Tehuantepec. Despite their relative abundance, variety, and nutritional value the current production of molluscs in the region is based on the exploitation of natural banks. Some species are collected from the estuaries and coastal lagoons for self-consumption or sell by local artisan fishermen to the restaurants and markets of small to medium communities along the coast. Many species are incidentally caught during shrimp fishing activities but only a few are usually delivered to the ports and consumed by men. Additionally, some shells are used as jewelry or used in handcrafts.

\section{Acknowledgments}

The authors wish to thank Christian Tovilla from ECOSURTapachula, for the invitation to his laboratory to perform this research and for all facilities during the fieldwork. They also thank the Centro Regional de Investigaciones Pesqueras (CRIP-INP) of Salina Cruz, Oaxaca for providing the molluscs from the continental shelf collected on board the shrimp vessel FIPESCO-63. The Secretaria de Marina in Puerto Chiapas and Candelario Manzanilla provided valuable logistic support during the sampling activities in the Suchiate and Cahoacan locations. They appreciate the suggestions made by two anonymous reviewers to improve the manuscript.

\section{References}

[1] R. C. Brusca and G. J. Brusca, Invertebrates, Sinauer Associates, Sunderland, Mass, USA, 1990.

[2] M. E. Hendrickx, R. C. Brusca, M. Cordero, and G. Ramírez, "Marine and brackish-water molluscan biodiversity in the Gulf of California, Mexico," Scientia Marina, vol. 71, no. 4, pp. 637-647, 2007.

[3] A. M. Keen, Seashells of Tropical West America. Marine Molluscs from Baja California to Peru, Stanford University Press, Palo Alto, Calif, USA, 1971.

[4] P. A. Morris, A Field Guide to the Pacific Coast Shells, Houghton Miffin, Boston, Mass, USA, 1966.

[5] R. T. Abbott, A Guide to Field Identification of the Sea Shells of North America, Golden Press, New York, NY, USA, 1968.

[6] R. T. Abbott and S. P. Dance, Compendium of Seashells, EP Dutton, New York, NY, USA, 1982.

[7] C. Skoglund, "Panamic Province molluscan literature. Addittions and changes from 1971 through 2000. I Bivalvia. II Polyplacophora," The Festivus, vol. 32, pp. 1-119, 2001.

[8] C. Skoglund, "Panamic Province molluscan literature. Addittions and changes from 1971 through 2001. III Gastropoda," The Festivus, vol. 33, pp. 1-286, 2002.

[9] R. H. Parker, "Zoogeography and ecology of some macroinvertebrates, particularly mollusks, in the Gulf of California 
and the continental slope off Mexico," Dansk Naturhistorisk Forening (Copenhagen), Videnskabelige Meddelelser, vol. 126, pp. 1-178, 1964.

[10] R. C. Brusca, Common Intertidal Inverterbrates of the Gulf of California, University of Arizona Press, Tucson, Ariz, USA, 1980.

[11] M. E. Hendrickx and A. Toledano-Granados, Catálogo de moluscos. Colección de referencia de la estación Mazatlán, ICMyL, UNAM, CONABIO-ICMyL, Coyoacán, Mexico, 1994.

[12] M. E. Hendrickx and R. C. Brusca, "Mollusca," in Distributional Checklist of the Macrofauna of the Gulf of California, México, M. E. Hendrickx and R. C. Brusca, Eds., pp. 159-273, Arizona-Sonora Desert Museum, Tucson, Ariz, USA, 2002.

[13] R. C. Brusca, E. Kimrey, and W. Moore, A Seashore Guide to the Northern Gulf of California, Arizona-Sonora Desert Museum, Tucson, Ariz, USA, 2004.

[14] R. C. Brusca, L. T. Findley, P. A. Hastings, M. E. Hendrickx, J. T. Cosió, and A. M. Van Der Heiden, "Macrofaunal diversity in the Gulf of California," in Biodiversity, Ecosystems, and Conservation in Northern Mexico, J. L. E. Cartron, G. Ceballos, and R. S. Felger, Eds., pp. 179-203, Oxford University Press, New York, NY, USA, 2005.

[15] P. Zamorano and M. E. Hendrickx, "Biocenosis y distribución de los moluscos de aguas profundas en el Pacífico mexicano: una evaluación de los avances," in Estudios Sobre la Malacología y conquiliología en México, E. Ríos-Jara, M. C. Esqueda-González, and C. M. Galván-Villa, Eds., pp. 48-49, Universidad de Guadalajara, Guadalajara, Mexico, 2007.

[16] M. E. Hendrickx, R. C. Brusca, and L. T. Findley, A Distributional Checklist of the Macrofauna of the Gulf of California, México. Part I. Invertebrates (Listado y distribución de la macrofauna del Golfo de California, México, Parte I. Invertebrados), Arizona-Sonora Desert Museum, Tucson, Ariz, USA, 2005.

[17] L. C. González-Bulnes, Algunos aspectos taxonómicos y distribución de los moluscos del Golfo de Tehuantepec, México, Undergraduate thesis, Universidad Nacional Autónoma de México, Coyoacán, Mexico, 1981.

[18] P. Gómez-Farías, Estudio de las comunidades de moluscos bentónicos en la costa de Salina Cruz, Oaxaca, Undergraduate thesis, Universidad Nacional Autónoma de México, Coyoacán, Mexico, 1985.

[19] D. G. Sandoval, Estudio de las comunidades bénticas de la zona rocosa litoral y sublitoral de localidades en bahías de Huatulco, Oaxaca, Undergraduate thesis, Universidad Nacional Autónoma de México, Coyoacán, Mexico, 1988.

[20] M. G. De León-Herrera, "Listado taxonómico de las especies de moluscos en la zona central del litoral Oaxaqueño," Ciencia y Mar, vol. 12, no. 4, pp. 49-51, 2000.

[21] C. A. Rodríguez-Palacios, L. M. Michel-Arana, G. SandovalDíaz, P. Gómez, and G. Green, "Los moluscos de las Bahías de Huatulco y Puerto Ángel, Oaxaca. Distribución, diversidad y abundancia," Universidad y Ciencia, vol. 5, no. 9, pp. 85-94, 1988.

[22] O. E. Holguín-Quiñones and P. González-Pedraza, Moluscos de la franja Costera del estado de Oaxaca, México. Atlas CICIMAR 7, CICIMAR-IPN, La Paz, Mexico, 1989.

[23] M. L. Sevilla-Hernández, Moluscos de la Franja Costera de Chiapas, México, Instituto Politécnico Nacional, Mexico City, Mexico, 1995.

[24] Secretaría de Pesca, Anuario Estadístico de Pesca, Secretaria de Pesca, San Jeronimo Aculco, Mexico, 1990.
[25] E. García, Modificaciones al sistema de clasificación climática de Koeppen, Instituto de Geografía. Universidad Nacional Autónoma de México, Coyoacán, Mexico, 2nd edition, 1973.

[26] Secretaría de Marina, Estudio geográfico del puerto de Salina Cruz, Oaxaca, Departamento de Hidrología, Merida, Mexico, 1974.

[27] A. Carranza-Edwards, "Estudio sedimentológico de playas del estado de Chiapas, México," Anales del Instituto de Ciencias del Mar y Limnología, UNAM, vol. 13, no. 1, pp. 231-244, 1986.

[28] P. Bouchet and J. P. Rocroi, "Classification and nomenclator of gastropod families," Malacologia, vol. 47, no. 1-2, pp. 1-397, 2005.

[29] A. Ramírez-González and N. A. Barrientos-Luján, "Moluscos de la zona intermareal de Cacaluta, bahías de Huatulco, Oaxaca, México," in Estudios sobre la Malacología y Conquiliología en México, E. Ríos-Jara, M. C. Esqueda-González, and C. M. Galván-Villa, Eds., pp. 280-282, Universidad de Guadalajara, Guadalajara, Mexico, 2007.

[30] R. T. Abbott, American Seashells. The Marine Mollusca of Atlantic and Pacific. Coast of North America, Van Nostrand Reinhold, New York, NY, USA, 1974.

[31] E. V. Coan, "Eastern Pacific species of the venerid genus Cyclinella (Bivalvia)," Veliger, vol. 44, no. 4, pp. 348-361, 2001.

[32] E. V. Coan, "The eastern Pacific recent species of the Corbulidae (Bivalvia)," Malacología, vol. 44, no. 1, pp. 47-105, 2002.

[33] V. E. Coan and P. Valentich-Scott, "Tellina inaequistrata Donova, 1802: A double neotype designation to stabilize nomenclature," The Festivus, vol. 37, no. 4, pp. 39-43, 2005.

[34] R. A. Cruz-Soto and J. A. Jiménez, Moluscos asociados a las áreas de manglar de la costa Pacífica de América central, Fundación UNA, Heredia, Costa Rica, 1994.

[35] K. Roy, D. Jablonski, and J. W. Valentine, "Dissecting latitudinal diversity gradients: functional groups and clades of marine bivalves," Proceedings of the Royal Society of London, vol. 267, no. 1440, pp. 293-299, 2000.

[36] K. Roy, D. Jablonski, J. W. Valentine, and G. Rosenberg, "Marine latitudinal diversity gradients: tests of causal hypotheses," Proceedings of the National Academy of Sciences of the United States of America, vol. 95, no. 7, pp. 3699-3702, 1998.

[37] J. W. Valentine, "Numerical analysis of marine molluscan ranges on the extratropical northeastern Pacific shelf," Limnology \& Oceanography, vol. 11, no. 2, pp. 198-211, 1966.

[38] K. Roy, D. Jablonski, and J. W. Valentine, "Eastern Pacific molluscan provinces and latitudinal diversity gradient: no evidence for 'Rapoport's Rule," Proceedings of the National Academy of Sciences of the United States of America, vol. 91, no. 19, pp. 8871-8874, 1994.

[39] K. J. Gaston, "Global patterns in biodiversity," Nature, vol. 405, no. 6783 , pp. $220-227,2000$.

[40] M. Pérez-Peña and E. Ríos-Jara, "Gastropod mollusks from the continental shelf off Jalisco and Colima, México: species collected with a trawling net," Ciencias Marinas, vol. 24, pp. 425-442, 1998.

[41] E. Ríos-Jara, E. López-Uriarte, and C. M. Galván-Villa, "Bivalve mollusks from the continental shelf of Jalisco and Colima, Mexican central Pacific," American Malacological Bulletin, vol. 26, pp. 119-131, 2008.

[42] J. C. Briggs, "Species diversity: land and sea compared," Systematic Biology, vol. 43, no. 1, pp. 130-135, 1994.

[43] E. O. Wilson, "Rain forest canopy: the high frontier," National Geographic Magazine, vol. 180, pp. 78-107, 1991. 
[44] L. Arriaga-Cabrera, E. Vázquez-Domínguez, J. GonzálezCano, R. Jiménez-Rosenberg, E. Muñoz-López, and V. Aguilar-Sierra, Regiones marinas prioritarias de México, Comisión Nacional para el Conocimiento y uso de la Biodiversidad, Mexico City, Mexico, 1998.

[45] E. Palacios-Espinosa, "Tipos De Vegetación," in Chiapas y su Biodiversidad, M. Álvarez-Del Toro, T. G. Cabrera-Cachón, C. A. Guichard-Romero, A. Ramírez-Velázquez, and G. J. CartasHeredia, Eds., pp. 27-54, Gobierno del Estado de Chiapas, Chiapas, Mexico, 1993.

[46] D. M. Olson, E. Dinerstein, G. Cintrón, and P. Lolster, A Conservation Assessment of Latin America and the Caribbean: Report from WWF's Conservation Assessment of Mangrove Ecosystems of Latin America and the Caribbean Workshop, WWF, Washington, DC, USA, 1996.

[47] P. Bouchet, P. Lozouet, P. Maestrati, and V. Heros, "Assessing the magnitude of species richness in tropical marine environments: exceptionally high numbers of molluscs at a New Caledonia site," Biological Journal of the Linnean Society, vol. 75, no. 4, pp. 421-436, 2002.

[48] T. A. Schlacher, P. Newell, J. Clavier, M. A. SchlacherHoenlinger, C. Chevillon, and J. Britton, "Soft-sediment benthic community structure in a coral reef lagoon theprominence of spatial heterogeneity and 'spot endemism," Marine Ecology Progress Series, vol. 174, pp. 159-174, 1998.

[49] S. Ortega, "Habitat segregation and temporal variation in some tropical intertidal populations," Journal of Experimental Marine Biology and Ecology, vol. 113, no. 3, pp. 247-265, 1987.

[50] G. A. Williams, "Seasonal variation in algal species richness and abundance in the presence of molluscan herbivores on a tropical rocky shore," Journal of Experimental Marine Biology and Ecology, vol. 167, no. 2, pp. 261-275, 1993.

[51] C. Olabarria, J. L. Carballo, and C. Vega, "Spatio-temporal changes in the trophic structure of rocky intertidal mollusc assemblages on a tropical shore," Ciencias Marinas, vol. 27, no. 2, pp. 235-254, 2001.

[52] R. M. Warwick and J. Light, "Death assemblages of molluscs on St Martin's flats, Isles of Scilly: a surrogate for regional biodiversity?" Biodiversity and Conservation, vol. 11, no. 1, pp. 99-112, 2002.

[53] R. M. Warwick and S. M. Turk, "Predicting climate change effects on marine biodiversity: comparison of recent and fossil molluscan death assemblages," Journal of the Marine Biological Association of the United Kingdom, vol. 82, no. 5, pp. 847-850, 2002.

[54] S. D. A. Smith, "Interpreting molluscan death assemblages on rocky shores: are they representative of the regional fauna?" Journal of Experimental Marine Biology and Ecology, vol. 366, no. 1-2, pp. 151-159, 2008.

[55] S. M. Kidwell and D. W. J. Bosence, "Taphonomy and timeaveraging of marine shelly faunas," in Taphonomy: Releasing the Data Locked in the Fossil Record, P. A. Allison and D. E. G. Briggs, Eds., pp. 115-209, Plenum Press, New York, NY, USA, 1991.

[56] S. M. Kidwell, "Preservation of species abundance in marine death assemblages," Science, vol. 294, no. 5544, pp. 1091-1094, 2001.

[57] S. M. Kidwell, "Ecological fidelity of open marine molluscan death assemblages: effects of post-mortem transportation, shelf health, and taphonomic inertia," Lethaia, vol. 41, no. 3, pp. 199-217, 2008.

[58] A. Feige and F. T. Fursich, "Taphonomy of the recent mollusks of Bahia la Choya (Gulf of California, Sonora, Mexico)," Zitteliana, vol. 18, pp. 89-133, 1991.
[59] S. M. Kidwell and K. W. Flessa, "The quality of the fossil record: populations, species, and communities," Annual Review of Ecology and Systematics, vol. 26, pp. 269-299, 1995.

[60] B. J. Greenstein and J. M. Pandolfi, "Preservation of community structure in modern reef coral life and death assemblages of the Florida Keys: implications for the quaternary fossil record of coral reefs," Bulletin of Marine Science, vol. 61, no. 2, pp. 431-452, 1997.

[61] S. M. Kidwell, "Time-averaged molluscan death assemblages: palimpsests of richness, snapshots of abundance," Geology, vol. 30, no. 9, pp. 803-806, 2002.

[62] R. Lockwood and L. R. Chastant, "Quantifying taphonomic bias of compositional fidelity, species richness, and rank abundance in molluscan death assemblages from the upper Chesapeake Bay," Palaios, vol. 21, no. 4, pp. 376-383, 2006. 

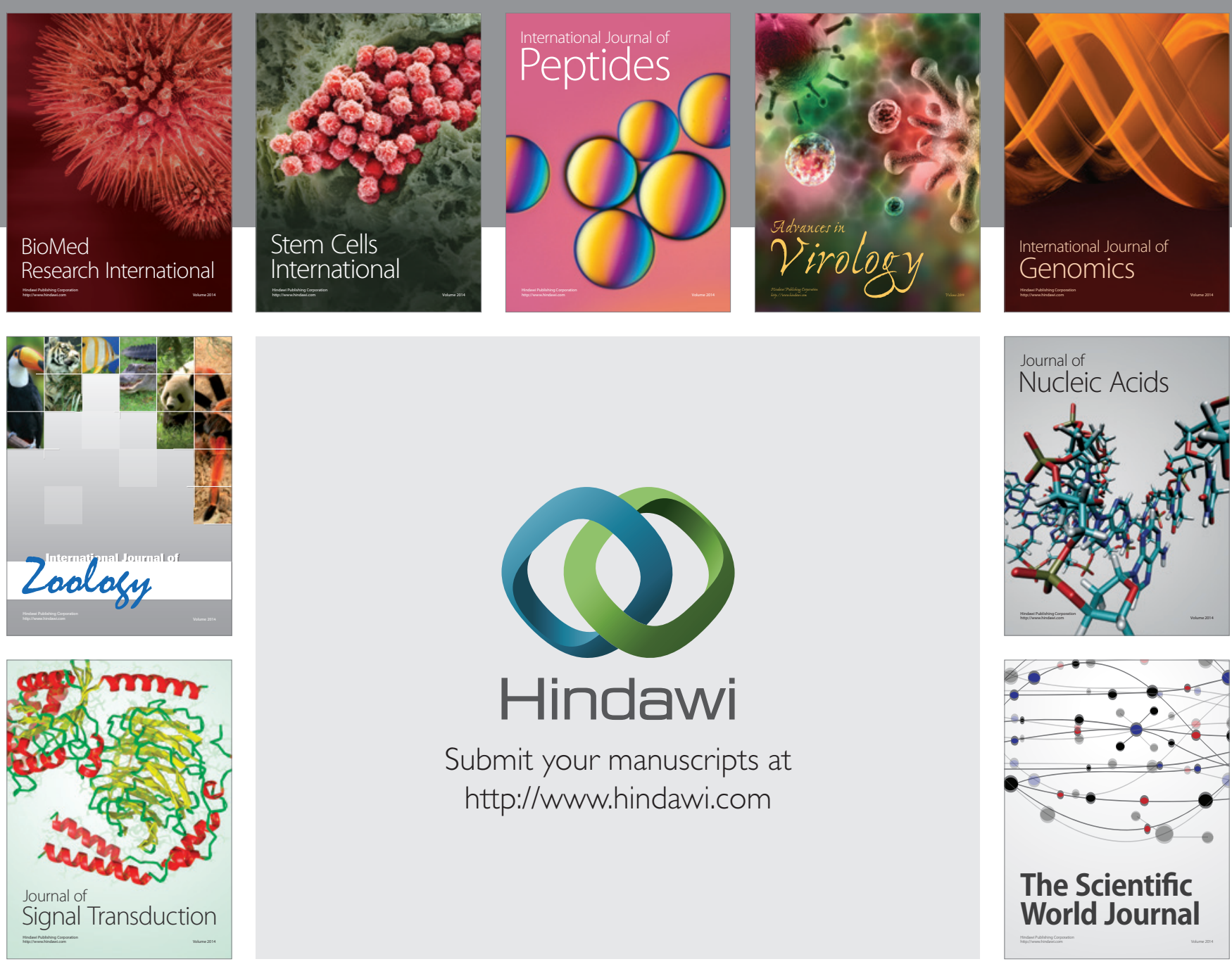

Submit your manuscripts at

http://www.hindawi.com
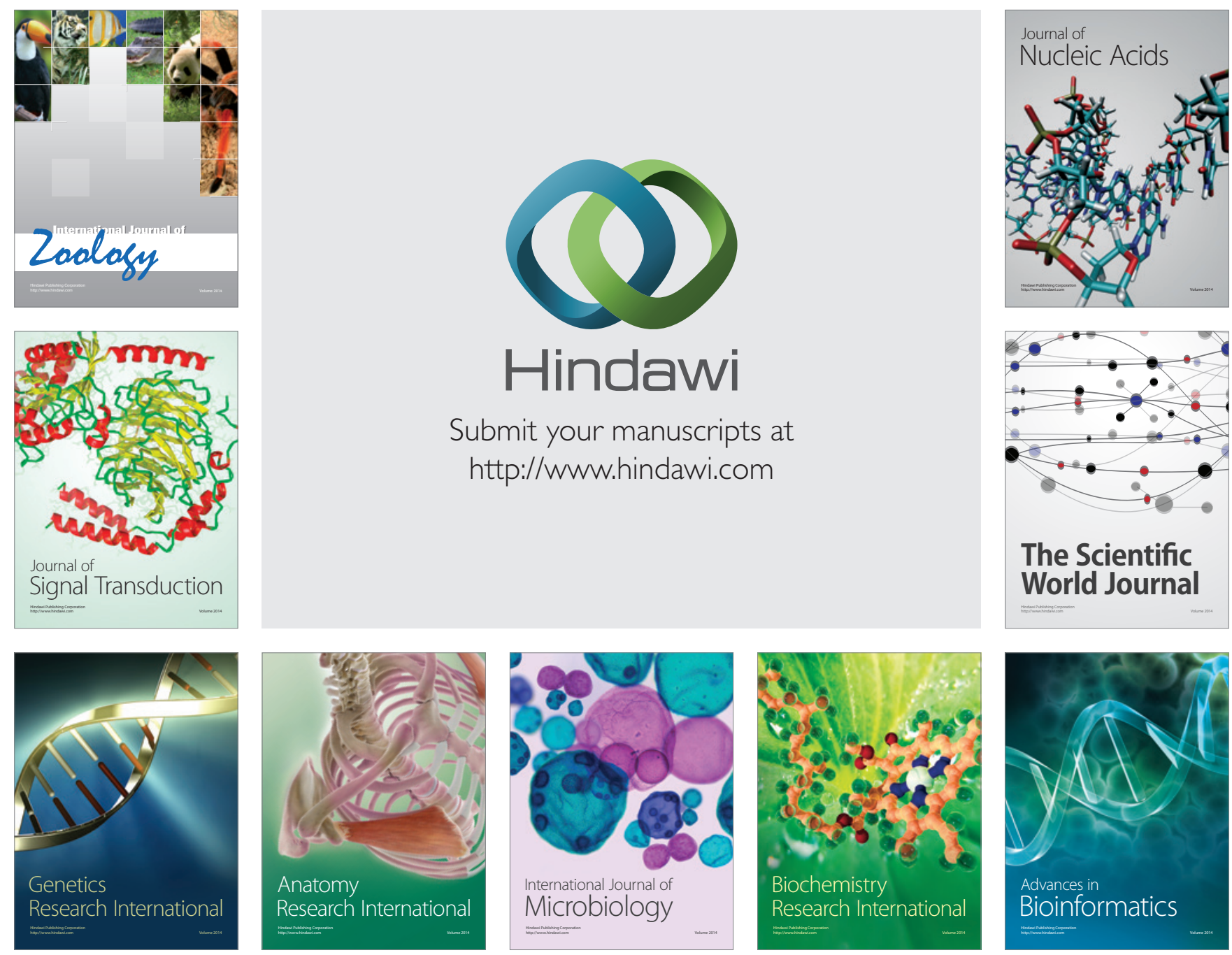

The Scientific World Journal
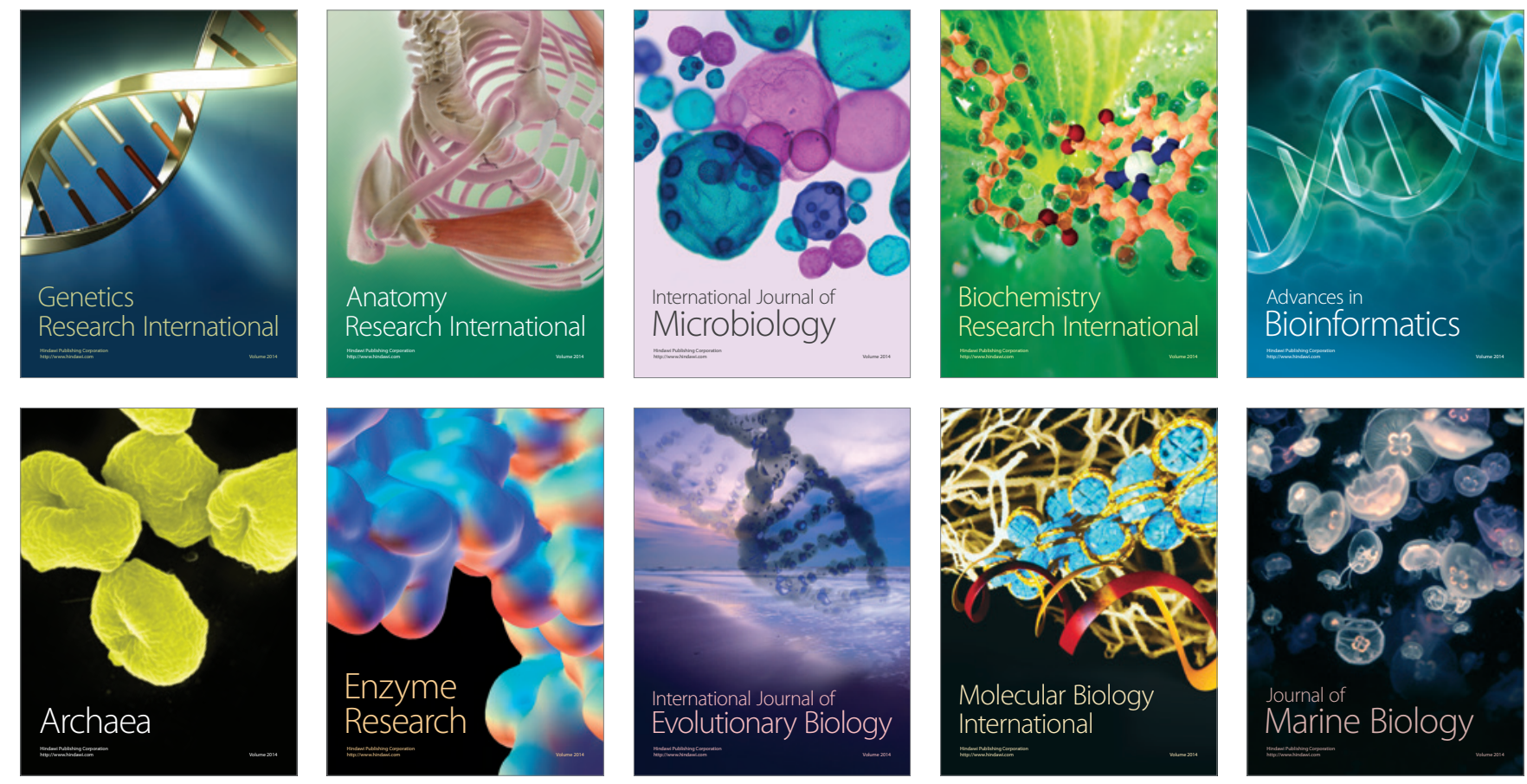